patients from nearby mental hospitals.

He showed in abundance the capacities both of psychiatric team leader and of managerial administrator so necessary to running a private hospital. After leaving Cheadle Royal he continued private psychiatric practice in Cheshire, first at Toft Hall and then at Alderley Edge.

A former lecturer at Manchester University on its old DPM course, he developed, in later years, adventurous unorthodox ideas on the causes of psychiatric illness from which stemmed highly individual methods of psychotherapy.

Latterly he had survived a number of heart attacks which diminished his traditional vigour. Our condolences go to his four children.

NK

\title{
Appeal to Preserve Psychiatric Memorabilia
}

For better or for worse, mental hospitals throughout the country are being closed, and seemingly will continue to be closed. There is a grave danger that important and irreplaceable documents and memorabilia of paramount historical importance may be destroyed in the process of these closures. I refer primarily to clinical records, administrative records, photographs as well as old ECT machines and the apparatus associated with deep insulin therapy clinics and the like.

May I therefore appeal to members to do their utmost to prevent this vandalism which is known to be going on. It may be that the College can accommodate some of this material, but, if not, the County Records Office is invariably glad to have them.

HENRY R. ROLLIN Honorary Librarian

\section{News Items}

\section{New Journals and Special Issues \\ Psychiatric Developments}

A new quarterly journal was launched last year called Psychiatric Developments, edited by Samuel B. Guze and Sir Martin Roth.

The rapid development of scientific inquiry in epidemiological, clinical and neurobiological aspects of psychiatry has created a need for authoritative, critical reviews to help those engaged in both research and practice to achieve an informed view of progress germane to their work. This journal aims to foster communication internationally and between disciplines so that those who have difficulty in keeping abreast of all the research into mental disorders may gain fresh perspectives and new insights. Further information is available from Oxford University Press, Walton Street, Oxford OX3 6DP.

\section{Nordisk Psykiatrisk Tidsskrift}

A recent issue of Nordisk Psykiatrist Tidsskrift (Nordic Psychiatric Review) (1983, Vol. 37, No. 3) presented a systematic survey of over 40 research projects completed in Norway in 1981 and 1982. Although descriptive text is in Norwegian, titles, subject and author indexes and main authors' addresses are given in English for each project. Copies of this special issue may be ordered from the publishers: Universitetsforlaget, PO Box 2977, Tøyen, Oslo 6, Norway, at US\$11 per copy.

\section{British Journal of Addiction}

In March 1984 the British Journal of Addiction publishes its centenary issue. This issue presents an historical perspective of the whole subject of addiction, including social, economic, political and medical effects. Topics covered include an examination of past alcohol and drug control policies in the UK and elsewhere, British smoking policies in the 1950s and 1960s and a study of the role of the WHO. The issue also features a special book review section. Information is available from Churchill Livingstone, Robert Stevenson House, 1-3 Baxter's Place, Leith Walk, Edinburgh EH1 3AF. (Individual issue: $£ 11$.)

\section{Helping the Overseas Trainee}

In recent years the College has become aware of the potential difficulties of overseas graduates and has established the Overseas Trainees' Sub-Committee (Sub-Committee of the Education Committee) to identify and advise the College about various issues. This committee has now produced a booklet which aims to alert all psychiatrists to these difficulties and to outline practical ways of assistance so that overseas trainees who experience difficulties can receive appropriate assistance. Copies of the booklet are available (free of charge) on request from Miss Jane Boyce at the College address. 